\title{
EFEKTIVITAS PASAL 34 HURUF b PERATURAN BANK INDONESIA NO.18/40/PBI/2016 TENTANG PENYELENGGARAAN PEMROSESAN TRANSAKSI PEMBAYARAN, MELALUI KARTU KREDIT DI KABUPATEN BANYUMAS \\ Oleh: Tengku Dezrina Citra Perdana ${ }^{1}$
}

\begin{abstract}
In recent times banking customers in the country have been quite troubled by the rampant act of data theft and falsification of customer data which in some cases has cost customers a lot. One of them is done by double swipe on a credit card. Therefore Bank Indonesia prohibits it through Article 34 letter b of Bank Indonesia Regulation No.18 / 40 / $P B I / 2016$ concerning the processing of payment transactions.

Article 34 Letter b Bank Indonesia Regulation No.18 / 40 / PBI / 2016 concerning the Implementation of payment transaction processing, through credit cards in Banyumas Regency has not been effective, because the legal purpose of Article 34 letter $b$ and PBI is not achieved. Judging from the level of effectiveness it is also less effective, because the level of effectiveness is related to compliance and legal compliance. Some legal subjects are not obedient and obedient to the prohibition Article 34 Letter b of the PBI. Factors that hinder the application of Article 34 letter $b$ of Bank Indonesia Regulation No.18 / 40 / PBI / 2016 concerning the implementation of payment transaction processing, through credit cards in Banyumas Regency. that is, law enforcement factors, namely Bank Indonesia, an indirect supervision system that is only based on reports from the public. Facility factors, socialization both through print and electronic media and counseling to the Acquirer, which are not optimal and lack direction. Community factors, level of discipline, and lack of community legal awareness. Cultural factors, lack of public culture, no matter the risk and the importance of prohibiting double swipe card activities on EDC (Electronic Data Capture) machines.

Keywords: Effectiveness, Credit Card, and Payment Transactions
\end{abstract}

\begin{abstract}
ABSTRAK
Beberapa waktu belakangan ini para nasabah perbankan di tanah air cukup diresahkan dengan maraknya tindakan pencurian data dan pemalsuan data nasabah yang dalam beberapa kasus banyak merugikan nasabah. Salah satunya dilakukan dengan cara penggesekan ganda (Double swipe) pada kartu kredit. Oleh karena itu Bank Indonesia melarangnya melalui Pasal 34 huruf b Peraturan Bank Indonesia No.18/40/PBI/2016 tentang penyelenggaraan pemrosesan transaksi pembayaran.

Pasal 34 Huruf b Peraturan Bank Indonesia No.18/40/PBI/2016 tentang Penyelenggaraan pemrosesan transaksi pembayaran, melalui kartu kredit di Kabupaten Banyumas belum efektif, karena tujuan hukum dari Pasal 34 huruf $b$ dan PBI tersebut tidak tercapai. Dilihat dari tingkat efektivitasnya juga kurang efektif, karena tingkat efektivitas terkait dengan ketaatan dan kepatuhan hukum. Beberapa subyek hukum ada yang belum taat dan patuh terhadap larangan Pasal 34 Huruf b PBI tersebut. Faktorfaktor yang menghambat berlakunya Pasal 34 huruf b Peraturan Bank Indonesia No.18/40/PBI/2016 tentang penyelenggaraan pemrosesan transaksi pembayaran, melalui kartu kredit di Kabupaten Banyumas. yaitu, faktor penegakan hukum, yaitu Bank Indonesia, sistem pengawasan tidak langsung yang hanya berdasarkan laporan dari masyarakat. Faktor fasilitas, sosialisasi baik melalui media cetak maupun elektronik dan penyuluhan kepada Acquirer, yang belum optimal dan kurang terarah. Faktor masyarakat, tingkat disiplin, dan kurangnya kesadaran hukum masyarakat. Faktor
\end{abstract}

\footnotetext{
${ }^{1}$ E-Mail : tlisiani@gmail.com
} 
1463 | J u r n a I I d e a H u k u m

Vol. $5 \mathrm{No} .2$ Oktober 2019

Magister IImu Hukum Universitas Jenderal Soedirman

budaya, kurangnya budaya publik, tidak peduli risiko dan pentingnya melarang aktivitas kartu gesek ganda pada mesin EDC (Electronic Data Capture).

Kata kunci : Efektivitas, Kartu Kredit, dan Transaksi Pembayaran.

\section{A. Pendahuluan}

Beberapa waktu belakangan ini, para nasabah perbankan di tanah air cukup diresahkan dengan maraknya aksi pencurian dan pemalsuan data nasabah yang dalam beberapa kasus banyak merugikan nasabah. Pencurian dan pemalsuan data nasabah tersebut salah satunya dilakukan melalui cara penggesekan ganda (Double swipe) pada kartu kredit maupun kartu debit. Awal September 2017 lalu, Pemerintah melalui Bank Indonesia (BI), telah menyatakan bahwa praktik Double swipe kartu kredit maupun kartu debit kini sudah dilarang. Hal ini dilakukan bukan tanpa alasan, namun demi menjaga perlindungan data pribadi dari nasabah yang bersangkutan. Pelarangan penggesekan ganda tersebut bertujuan untuk melindungi masyarakat dari pencurian data dan informasi kartu.

Peraturan yang melarang penggesekan ganda kartu kredit maupun kartu debit di mesin EDC (Electronic Data Capture) dan mesin kasir ini sudah diatur dalam Peraturan Bank Indonesia (PBI) No. 18/40/PBI/2016 tentang

Penyelenggaraan

Pemrosesan

Transaksi Pembayaran. Aturan tersebut dapat dilinat pada PBI No.18/40/PBI/2016 dalam bab VIII tentang larangan Pasal 34 menyebutkan, Penyelenggara Jasa Sistem Pembayaran dilarang:

a. melakukan pemrosesan transaksi pembayaran dengan menggunakan virtual currency;

b. menyalahgunakan data dan informasi nasabah maupun data dan informasi transaksi pembayaran; dan/atau

c. memiliki dan/atau mengelola nilai yang dapat dipersamakan dengan nilai uang yang dapat digunakan di luar lingkup Penyelenggara Jasa Sistem Pembayaran yang bersangkutan.

Pada pasal 34 huruf $b$ tersebut melarang penyelenggara jasa sistem pembayaran menyalahgunakan data dan informasi nasabah maupun data dan informasi transaksi pembayaran selain untuk tujuan transaksi pemrosesan pembayaran. Tercakup di dalamnya adalah larangan pengambilan data melalui mesin kasir di pedagang.

Tujuan dibuatnya Peraturan bank Indonesia No.18/40/PBI/2016 secara tersirat dapat dilihat dalam ketentuan pasal 34 huruf $b$ dan penjelasan $\mathrm{PBI}$ itu sendiri ialah untuk memenuhi kebutuhan masyarakat, termasuk di bidang jasa sistem pembayaran, baik dari sisi instrumen, penyelenggara, mekanisme 
maupun infrastruktur penyelenggaraan pemrosesan transaksi pembayaran. Inovasi penyelenggaraan pemrosesan transaksi pembayaran yang perlu tetap mendukung terciptanya sistem pembayaran yang lancar, aman, efisien dan andal, degan memperhatikan aspek perlindungan konsumen.

PBI ini juga memuat mengenai penyelenggara dalam pemrosesan transaksi pembayaran, perizinan dan persetujuan dalam penyelenggaraan pemrosesan transaksi pembayaran. Kewajiban dalam penyelenggaraan pemrosesan transaksi pembayaran, laporan, peralihan izin penyelenggara jasa sistem pembayaran dan pengawasan, larangan serta sanksi. Kegiatan pemrosesan transaksi pembayaran dilakukan oleh Penyelenggara Jasa Sistem Pembayaran (PJSP) dan Penyelenggara Penunjang.

Pedagang atau perusahaan tempat kita berbelanja yang disebut sebagai Merchant bank juga merupakan salah satu pihak dalam pemrosesan transaksi pembayaran tersebut, yang mana telah dijelaskan pada PBI No. 18/4/PBI/2016 pasal 3 ayat (2) "Acquirer sebagaimana dimaksud pada ayat (1) huruf $d$ dan Penyelenggara Payment Gateway sebagaimana dimaksud pada ayat (1) huruf e merupakan penyelenggara yang termasuk dalam kategori merchant acquiring services". .
Bank Indonesia sebagai Bank Sentral juga merupakan lembaga yang ikut berperan serta dalam mengatur, menjaga, melakukan pengawasan serta yang menindak tegas dalam hal ini memberi sanksi dalam penyelenggaraan pemrosesan transaksi pembayaran apabila terjadi hal yang tidak sesuai dengan PBI tersebut yang dilakukan oleh penyelenggara jasa sistem pembayaran (PJPS) dan Penyelenggara penunjang.

Bank Indonesia guna memperhatikan aspek perlindungan konsumen memberlakukan kewajiban izin atau persetujuan atas penyelenggaraan jasa sistem pembayaran oleh pihak yang belum tercakup dalam ketentuan Bank Indonesia saat ini. Dalam rangka menjaga kedaulatan industri sistem pembayaran nasional dan penguatan aspek perlindungan konsumen, khususnya terkait dengan pengamanan data dan dana masyarakat Indonesia.

Posisi konsumen menjadi yang paling lemah karena tidak dapat berbuat banyak, oleh karena itu untuk tercapainya efektivitas Pasal 34 huruf $b$ PBI No.18/40/PBI/2016 dalam hal penyelenggaraan pemrosesan transaksi pembayaran sehingga menimbulkan keamanan dan kenyamanan bagi semua pihak, perlu dilihat kembali lima faktor yang menentukan apakah aturan pasal 34 huruf b PBI 18/40/PBI/2016 tersebut efektif atau tidak, yaitu : 
1465 | Ju rn a I I de a H u k u m

Vol. $5 \mathrm{No} .2$ Oktober 2019

Magister IImu Hukum Universitas Jeenderal Soedirman

1. faktor hukumnya sendiri

2. faktor penegak hukum, yaitu pihak-pihak yang membentuk maupun menerapkan hukum

3. faktor sarana atau fasilitas yang mendukung penegakan hukum

4. faktor masyaraat, yakni lingkungan dimana hukum tersebut berlaku atau diterapkan

5. faktor kebudayaan, yakni sebagai hasil karya, cipta dan rasa yang didasarkan pada karsa manusia di dalam pergaulan hidup. ${ }^{2}$

Bank Indonesia $(\mathrm{BI})$ yang bertindak sebagai pengawas dalam penyelenggaraan pemrosesan transaksi pembayaran akan menindak tegas pelaku atau Merchant yang melakukan penggesekan ganda (Double swipe) pada mesin kasir dan mesin electronic data capture (EDC). Hal tersebut karena masih banyak Acquirer, bank atau lembaga selain bank yang bekerja sama dengan Merchant, membiarkan gesek ganda di mesin kasir. Sanksinya bisa berupa teguran, denda, pemberhentian sementara, dan cabut izin pelaksananya

\section{B. METODE PENELITIAN}

Penelitian

menggunakan metode pendekatan secara yuridis sosiologi. Spesifikasi yang dipergunakan dalam

\footnotetext{
${ }^{2}$ Soerjono Soekanto, 2008, Faktor-Faktor yang mempengaruhi Penegakan Hukum, Raja Grafindo Persada, Jakarta, hlm.8
}

penelitian ini adalah penelitian secara deskriptif analisis ${ }^{3}$.

\section{Sifat Penelitian}

\section{Subjek Penelitian}

Bank Indonesia,

Merchant, Acquirer dan

Konsumen yang

melakukan transaksi

menggunakan kartu kredit

di kabupaten Banyumas

\section{Data Penelitian}

Data yang digunakan dalam penelitian ini adalah data sekunder. Data Sekunder terdiri dari

a. Undang-Undang Nomor 8 Tahun 1999 tentang Perlindungan Konsumen;

b. Undang-Undang Nomor 6 Tahun 2009 Tentang Bank Indonesia

c. Peraturan Bank Indonesia No 18/40/PBI/2016 tentang

Penyelenggaraan

Pemrosesan

Transaksi

Pembayaran PP

Nomor 9 Tahun 1975.

\footnotetext{
3 Bambang Sunggono, 2006, Metode Penelitian Hukum, PT Raja Grafindo Persada, Jakarta, hlm. 35
} 


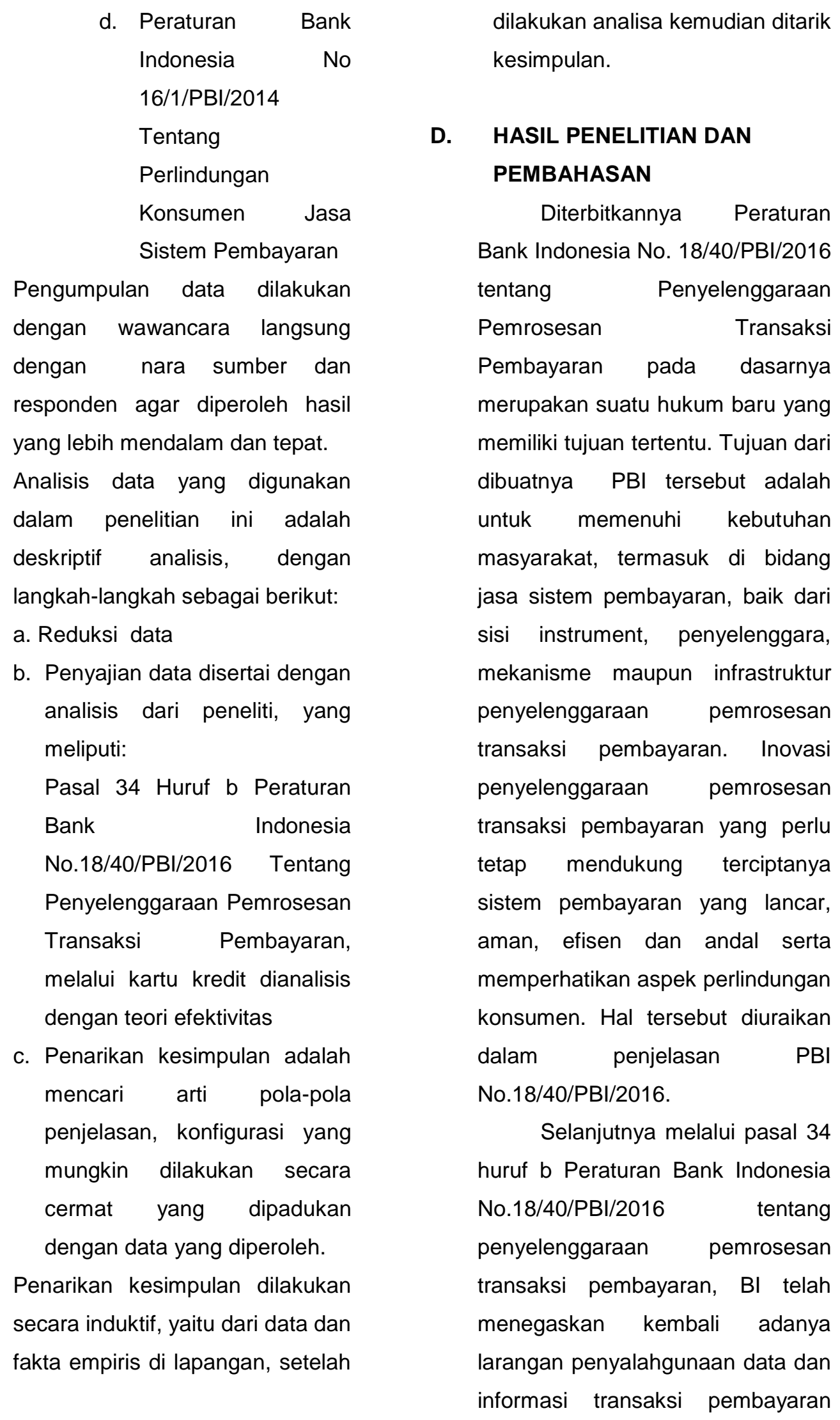


1467 | J u rn a I I d e a H u k u m

Vol. $5 \mathrm{No} .2$ Oktober 2019

Magister IImu Hukum Universitas Jenderal Soedirman

nasabah, selain untuk tujuan pemrosesan transaksi pembayaran, misalnya terkait praktik Double swipe. yang dijelaskan secara rinci oleh penjelasan Pasal 34 huruf b yaitu yang dimaksud dengan "menyalahgunakan data dan informasi" adalah pengambilan atau penggunaan data selain untuk tujuan pemrosesan transaksi pembayaran misalnya pengambilan nomor kartu, card verification value, expiry date, dan/atau service code pada Kartu Debet/Kredit melalui cash register di pedagang (Double swipe).

Berdasarkan hal tersebut yang menjadi pertanyaan adalah efektif atau tidaknya Pasal 34 huruf b PBI No.18/40/PBI/2016 tersebut. Berbicara mengenai efektif atau tidaknya suatu peraturan, maka haruslah diketahui terlebih dahulu apa defenisi dari efektivitas itu sendiri. Efektivitas berarti bahwa tujuan yang telah direncanakan sebelumnya dapat tercapai atau dengan kata lain sasaran tercapai karena adanya proses kegiatan. ${ }^{4}$ Tingkat efektivitas dapat diukur dengan membandingkan antara rencana atau target yang telah ditentukan dengan hasil yang dicapai, maka usaha atau hasil pekerjaan tersebut itulah yang

${ }^{4}$ Prasolong Harbani, 2007, Teori Aministrasi Publik, Alfabeta, Bandung, HIm.10 dikatakan efektif, namun jika usaha atau hasil pekerjaan yang dilakukan tidak tercapai sesuai dengan apa yang direncanakan, maka hal tersebut dikatakan tidak efektif. Dengan demikian peraturan $\mathrm{PBI}$ tersebut dikatakan efektif atau tidak efektif jika tujuan peraturan tersebut tercapai. Tingkat efektifitas dapat diukur dengan membandingkan antara tujuan dibuatnya peraturan tersebut dengan kondisi yang ada setelah peraturan itu dilaksanakan.

Sebelum dikeluarkannya aturan mengenai Pasal 34 Huruf $b$ PBI N018/40/PBI/2016 tersebut, Pada tahun 2013 industri sistem pembayaran pernah terhentak manakala terjadi kasus pencurian ribuan data kartu pembayaran konsumen di sistem komputer sebuah toko ritel yang menyebabkan kerugian miliyaran rupiah bagi nasabah dan perbankan $^{5}$ Tidak lama setelah insiden tersebut Bank Indonesia mengeluarkan surat edaran yang ditujukan kepada semua bank berisi imbauan untuk menghentikan praktek Double swiping oleh toko (Merchant).

\footnotetext{
${ }^{5}$ Liputan6, Kronologi Kasus Pencurian Data Kartu Kredit Di Body Shop, https://www.liputan6.com/bisnis/read/544 093/kronologi-kasus-pencurian-data-kartukredit-di-body-shop. Diakses tgl 10 januari 2018
} 


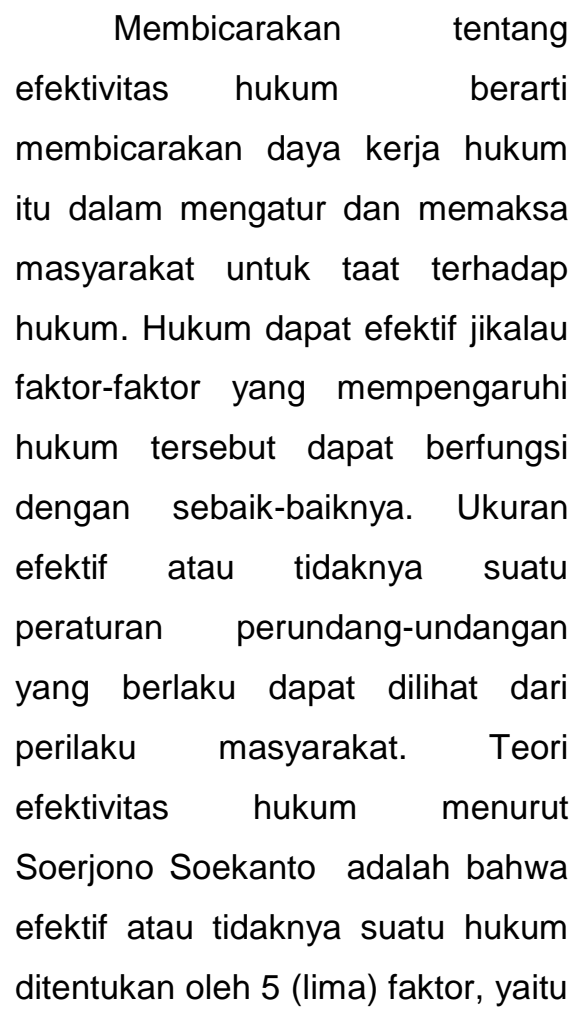

1. Faktor hukumnya sendiri (Undang-Undang).

2. Faktor penegak hukum, yakni pihak-pihak yang membentuk maupun menerapkan hukum.

3. Faktor sarana atau fasilitas yang mendukung penegakan hukum.

4. Faktor masyarakat, yakni lingkungan dimana hukum tersebut berlaku atau diterapkan.

5. Faktor kebudayaan, yakni sebagai hasil karya, cipta dan rasa yang didasarkan pada karsa manusia di dalam pergaulan hidup. ${ }^{6}$

Kelima faktor diatas saling berkaitan dengan eratnya, oleh karena merupakan esensi dari penegakan hukum, juga merupakan tolak ukur dari efekitvitas penegakan hukum.

Faktor pertama berdasarkan teori efektivitas dari Soerjono Soekanto adalah faktor hukumnya itu sendiri, yang menentukan dapat berfungsinya hukum tertulis tersebut dengan baik atau tidak. ${ }^{7}$ Hal ini senada dengan Ahmad Mujahidin yang menyatakan bahwa, pada intinya yang dimaksud dengan substansi hukum/ faktor hukum adalah hasil - hasil yang diterbitkan oleh sistem hukum, mencakup aturan - aturan hukum, baik yang tertulis maupun yang tidak tertulis. ${ }^{8}$ Aturan hukum yang dimaksud dalam penelitian ini adalah Pasal 34 huruf b Peraturan Bank Indonesia No.18/40/PBI/2016 tentang Penyelenggaraan Pemrosesan Transaksi Pembayaran. PBI tersebut sudah memuat dengan jelas tujuan, aturan, larangan serta sanksi tegas yang mengatur semua tentang

\footnotetext{
${ }^{6}$ Soerjono Soekanto, Op.cit, hlm.8

${ }^{7}$ Soerjono Soekanto, Op.cit, hlm.4

${ }^{8}$ Ahmad Mujahidin, 2007, Peradilan Satu Atap Diindonesia, Bandung: Refika Aditama, hlm. 42
} 
1469 | Jurna I | d e a Hukum

Vol. $5 \mathrm{No} .2$ Oktober 2019

Magister IImu Hukum Universitas Jenderal Soedirman

penyelenggaraan pemrosesan transaksi pembayaran.

Sehingga dalam suatu
proses penegakan hukum, faktor
hukum adalah salah satu yang
menentukan keberhasilan
penegakan hukum itu sendiri.
namun tidak terlaksananya
penegakan hukum dengan
sempurna hal itu disebabkan
karena terjadi masalah atau
gangguan yang disebabkan karena beberapa hal seperti tidak diikuti asas-asas berlakunya undangundang yang merupakan dasar pedoman dari suatu peraturan perundang-undangan, hal yang kedua yaitu belum adanya suatu aturan pelaksanaan untuk menerapkan undang-undang. ${ }^{9}$

Peraturan Bank Indonesia No.18/40/PBI/2016 tentang Penyelenggaraan Pemrosesan Transaksi Pembayaran sudah memuat dengan jelas tujuan, aturan, larangan serta sanksi tegas yang mengatur semua tentang penyelenggaraan pemrosesan transaksi pembayaran. Terkait di dalamnya larangan tegas terhadap Double swipe yang dilakukan oleh toko. Hal ini dijelaskan lebih rinci di dalam penjelasan pasal 34 huruf $b$ yaitu yang dimaksud dengan "menyalahgunakan data dan

${ }^{9}$ Soerjono Soekanto, Op cit., hlm.5 informasi" adalah pengambilan atau penggunaan data selain untuk tujuan pemrosesan transaksi pembayaran misalnya pengambilan nomor kartu, card verification value, expiry date, dan/atau service code pada Kartu Debet/Kredit melalui cash register di pedagang (Double swipe). Dari faktor pertama ini dapat dilihat dari PBI itu sendiri sudah dibuat dengan cukup baik jelas dan mudah dimengerti oleh semua pihak.

Faktor kedua yaitu faktor penegak hukum, yakni pihak-pihak yang membentuk maupun menerapkan hukum, Bank Indonesia adalah salah satu. penegak hukum mempunyai peran yang penting dalam penegakan hukum itu sendiri, perilaku dan tingkah laku aparat pun seharusnya mencerminkan suatu kepribadian yang dapat menjadi teladan bagi masyarakat dalam kehidupan sehari-hari. Aparat penegak hukum yang profesional adalah mereka yang dapat berdedikasi tinggi pada profesi sebagai aparat hukum, dengan demikian seorang aparat penegak hukum akan dapat melaksanakan tugas dan kewenangannya sebagai seorang penegak hukum dengan baik. ${ }^{10}$

Bank Indonesia adalah pihak yang membentuk dan menerapkan

${ }^{10}$ Ibid., hlm. 34 
aturan $\mathrm{PBI}$ tersebut. $\mathrm{BI}$ dalam kapasitasnya yang memberikan izin terhadap PJSP dan juga melakukan pengawasan terkait izin yang diberikan. Selain BI pihak penerbit kartu kredit atau Acquirer juga bagian dari faktor penegak hukum itu sendiri. Bank Indonesia yang diwakili oleh divisi sistem pembayaran mensosialisasikan peraturan tersebut kepada masyarakat dan juga pihak bank. Dari hasil penelitian Bank Indonesia juga selaku pengawas sistem pembayaran masih kurang dalam menjalankan tugasnya sebagai pengawas dalam sistem pembayaran. Sedangkan tugas pengawasannya jelas diatur dalam PBI NO.18/40/PBI/2016 Pasal 33 tentang pengawasan. $\mathrm{Hal}$ ini berdasarkan hasil wawancara dengan Ageng Kharisma selaku Divisi sistem pembayaran Bank Indonesia di Purwokerto, dimana Bank Indonesia tidak melakukan pengawasan secara langsung, hanya terhadap laporan-laporan masyarakat saja. Selain menjadi penghubung atau mediasi antara konsumen dan pihak bank penerbit kartu, seharusnya Bank Indonesia juga bisa melaksanakan tugasnya untuk mengawasi langsung ke Merchant-merchant atau sidak langsung guna memberi sanksi tegas terhadap pemilik Merchant yang masih melakukan tindakan Double swipe.

Faktor ketiga sarana dan prasarana yang dimaksud adalah prasarana atau fasilitas yang digunakan sebagai alat untuk mencapai efektivitas hukum. Dengan dukungan sarana dan fasilitas yang memadai penegakan hukum akan dapat terlaksana dengan baik. Sarana dan fasilitas yang dimaksud, antara lain, sumber daya manusia, organisasi yang baik, peralatan yang mumpuni, dan sumber dana yang memadai. ${ }^{11}$

$\begin{array}{ccc}\text { Bank } & \text { Indonesia } & \text { dalam } \\ \text { melakukan } & \text { sosialisasi } & \text { selain }\end{array}$
mengadakan event sosialisasi, juga imbauan di media cetak maupun elektronik untuk mengedukasi para pemilik Merchant dan masyarakat untuk menjelaskan tentang PBI No.18/40/PBI/2016 dan larangan serta resiko praktik Double swipe, juga memberikan brosur atau selebaran yang berisi imbauan tentang larangan praktik Double swipe. Hal ini berdasarkan hasil wawancara dengan Ageng Kharisma Divisi sistem pembayaran Bank Indonesia. Sarana dan prasarana yang digunakan oleh Bank Indonesia sejauh ini sudah cukup baik, namun masih kurang optimal dalam menggencarkan

\footnotetext{
${ }^{11}$ Ibid., hlm. 37
} 
1471 J u rna | | d e a Hukum

Vol. $5 \mathrm{No} .2$ Oktober 2019

Magister IImu Hukum Universitas Jenderal Soedirman

sosialisasi. Event-event sosialisasi harusnya dilakukan ditempattempat seperti pusat perbelanjaan atau tempat-tempat yang mana pengguna kartu kredit banyak menggunakan kartu mereka untuk bertransaksi ditempat tersebut. Agar penyampaian kepada masyarakat bisa langsung diterima dengan baik dan tepat pada sasaran yang dituju, yaitu masyarakat yang melakukan transaksi pembayaran melalui kartu kredit maupun kartu debit.

Faktor keempat adalah faktor masyarakat, Penegakan hukum adalah berasal dari masyarakat dan untuk masyarakat. Oleh karena itu peran masyarakat dalam penegakan hukum juga sangat menentukan. Masyarakat yang sadar hukum tentunya telah mengetahui hal mana yang merupakan hak dan kewajiban mereka, dengan demikian mereka akan mengembangkan kebutuhankebutuhan mereka sesuai dengan aturan yang berlaku. ${ }^{12}$ dalam penelitian ini tingkat disiplin dan kepatuhan masyarakat terhadap aturan hukum tersebut menjadi salah satu parameter penting untuk mengukur tingkat efektif atau tidaknya hukum itu diberlakukan.

Berdasarkan hasil penelitian didapatkan hasil banyak sekali

${ }^{12}$ Ibid., hlm. 57 masyarakat yang tidak mengetahui tentang sosialisasi $\mathrm{PBI}$ tersebut termasuk aturan, larangan, serta resiko dari Double swipe. Ada yang sekedar tahu tapi tidak peduli, banyak yang tidak tahu dan tidak peduli. Kepatuhan masyarakat terhadap hukum dan kesadaran nya terhadap hukum juga menjadi penekanan terhadap efektif atau tidaknya hukum tersebut. Apabila peraturan dari hukum itu sendiri sudah jelas,baik dan mudah dimengerti, namun kepatuhan dan kesadaran hukum dari masyarakat nya kurang maka tujuan dari $\mathrm{PBI}$ No.18/40/PBI/2016 yaitu terciptanya sistem pembayaran yang lancar, aman, efisien dan andal serta memperhatikan aspek pelindungan konsumen menjadi tidak efektif. Edukasi kepada masyarakat terhadap security awareness perlu lebih ditingkatkan. Apabila masyarakat dan semua pihak paham akan bahayanya double Swipe maka diharapkan tingkat kepatuhan dan kesadaran hukumnya meningkat.

Faktor kelima yaitu faktor kebudayaan. dalam praktik internasional (best practice) Double swiping juga dilarang keberadaannya tidak saja oleh bank sentral diberbagai Negara tapi juga oleh perbankan dan berbagai asosiasi sitem pembayaran. 
Bahkan di Australia, Double swipe tidak saja dilarang namun dikembangkan juga budaya bahwa kasir toko dilarang untuk memegang dan menggesek atau men-deep-in kartu pembayaran nasabah. Di Indonesia budaya atau kebiasaan yang berlaku adalah kasir toko yang memegang, menggesek bahkan men-deep-in kartu pembayaran nasabah ${ }^{13}$. Seringkali juga ditemui letak mesin EDC yang jauh dari jangkauan nasabah sehingga tidak dapat diawasi penggunaannya. berdasarkan hasil penelitian dan wawancara budaya masyarakat yang cuek dan tidak peduli membuat suatu aturan hukum menjadi tidak efektif. Sehingga tujuan dari Pasal 34 Huruf b PBI No.18/40/PBI/2016 yakni memenuhi kebutuhan masyarakat termasuk di bidang jasa sistem pembayaran agar dalam pemrosesan transaksi pembayaran tercipta sistem pembayaran yang lancar, aman, efisien dan andal serta memenuhi aspek perlindungan konsumen Walaupun aturan perangkat dan penegak hukumnya sudah baik tapi faktor

${ }^{13}$ Iwan Setiawan, Double Swiping dan Resiko Pencurian Data, https://economy.okezone.com/rad/2017/0 9/08/320/1771793/double-swiping-danresiko-pencurian-data\#lastread. Diakses pada tanggal 16 februari 2018 masyarakat dan budaya masyarakatnya tingkat kesadaran hukumnya rendah, maka tujuan dari hukum itu dibuat tidak akan tercapai.

I. PENUTUP

\section{Simpulan}

1. Pasal 34 Huruf b Peraturan Bank Indonesia No. 18/40/PBI/2016 tentang Penyelenggaraan Pemrosesan Transaksi Pembayaran melalui kartu kredit di Kabupaten Banyumas belum efektif, karena tujuan hukum dari Pasal 34 huruf $b$ dan $\mathrm{PBI}$ itu sendiri tidak tercapai. Selain itu tingkat efektivitas pasal 34 Huruf b PBI 18/40/PBI/2016 adalah kurang efektif, karena tingkat efektivitas berkaitan dengan ketaatan dan kepatuhan hukum. Beberapa subyek hukum ada yang belum taat dan patuh terhadap larangan Pasal 34 Huruf b PBI tersebut. Yaitu Bank Indonesia sebagai penegak hukum. Acquirer dalam memberikan penyuluhan, serta sosialisasi terhadap Merchant kurang maksimal. Kepatuhan hukum dari pihak Merchant yang masih melakukan praktik Double swipe. dan juga masyarakat atau konsumen yang tidak taat atau patuh terhadap hukum, serta kesadaran hukumnya yang 
1473 | J u rn a I I de a H u k u m

Vol. $5 \mathrm{No} .20 \mathrm{ktober} 2019$

Magister IImu Hukum Universitas Jenderal Soedirman

kurang, terhadap aturan, larangan serta resiko Double swipe tersebut.

2. Faktor-faktor yang menghambat berlakunya Pasal 34 Huruf $b$ Peraturan Bank Indonesia No. 18/40/PBI/2016 tentang Penyelenggaraan Pemrosesan Transaksi Pembayaran melalui kartu kredit di Kabupaten Banyumas dilihat dari lima faktor teori efektivitas Soerjono Soekanto.

- Faktor penegak hukum yaitu Bank Indonesia selain sistem pengawasannya yang masih kurang, pengawasan tidak langsung yang hanya berdasarkan laporan-laporan dari masyarakat, membuat sistem pengawasannya kurang maksimal. Ditambah dengan dibukanya contact center BICARA di 131, dimana masyarakat dapat mengadukan laporan-laporan langsung melalui BI BICARA dan hal tersebut langsung terfokus ke BI Pusat. Sehingga pengawasan di daerah-daerah kurang optimal.

- Faktor sarana atau fasilitas, dalam penelitian ini yang digunakan oleh Bank Indonesia adalah sosialisasi baik melalui media cetak maupun elektronik dan penyuluhan kepada bank-bank penerbit, yang dirasa belum optimal dan kurang tepat sasaran.

- Faktor masyarakat, berdasarkan hasil penelitian yang dilakukan oleh peneliti tingkat disiplin dan kepatuhan masyarakat sangat lah kurang. Dari hasil penelitian Masih banyak masyarakat yang tidak mengetahui tentang sosialisasi PBI tersebut beserta aturan, larangan serta resiko dari Double swipe.

- Faktor kebudayaan, budaya masyarakat yang kurang juga tidak peduli terhadap resiko dan pentingnya larangan aktivitas Double swipe kartu kredit pada mesin EDC (Electronic Data Capture). Kebiasaan para pengguna kartu kredit yang hanya memberikan kartu kredit pada saat melakukan pembayaran tanpa teliti, serta mengecek langsung dan bertanya bagaimana proses saat melakukan pembayaran di mesin kasir, hanya membayar lalu pergi. Membuat Peraturan Bank Indonesia No. 18/40/PBI/2016 tentang Penyelenggaraan Pemrosesan 
Transaksi Pembayaran, menjadi tidak efektif.

\section{Saran}

a. Perlunya peningkatan dan konsistensi terhadap ketaatan, kepatuhan, dan kesadaran hukum oleh semua pihak agar tujuan dan rencana dari dibuatnya Pasal 34 huruf b PBI No.18/40/PBI/2016 dapat dicapai dengan maksimal. Untuk terciptanya sistem pembayaran yang lancar, aman, efisien dan andal dengan memperhatikan aspek perlindungan terhadap konsumen.

b. Perlunya konsistensi Bank Indonesia sebagai penegak hukum dan regulator sistem pembayaran di Indonesia dengan cara memberikan efek jera kepada Penyelenggara transaksi sistem pembayaran yang melanggar ketentuan dan merugikan konsumen. serta perlunya pengawasan bank Indonesia yang bersifat langsung (inspeksi mendadak). Sosialisasi atau penyuluhan yang lebih ditingkatkan atau diaktifkan kembali kepada masyarakat, Acquirer dan Merchant dengan memfokuskan pada segi pengetahuan dan pemahaman resiko aktivitas Double swipe kartu kredit pada mesin EDC (Electronic Data Capture) pada tempat-tempat umum dimana

banyak konsumen sering melakukan transaksi menggunakan kartu kredit.

\section{DAFTAR PUSTAKA}

Harbani, Prasolong. 2007. Teori Aministrasi Publik. Alfabeta. Bandung.

Mujahidin, Ahmad. 2007. Peradilan Satu Atap Di Indonesia. Refika Aditama. Bandung

Soekanto, Soerjono. 2011. FaktorFaktor yang Mempengaruhi Hukum. PT.Raja Grafindo Persada. Jakarta

Sunggono, Bambang. 2006. Metode Penelitian Hukum. PT Raja Grafindo Persada. Jakarta.

Iwan Setiawan, Double Swiping dan Resiko Pencurian Data, tersedia di website https://economy.okezone.com/rad/2 017/09/08/320/1771793/doubleswiping-dan-resiko-pencuriandata\#lastread. Diakses pada tanggal 16 Februari 2018

Liputan6, Kronologi Kasus Pencurian Data Kartu Kredit Di Body Shop, tersedia di website https://www.liputan6.com/bisnis/rea d/544093/kronologi-kasuspencurian-data-kartu-kredit-dibody-shop. Diakses tanggal 10 januari 2018 